\title{
REDUCING MANUFACTURING LEAD TIME OF STEAM TURBINE
}

\section{CASING}

\author{
Nagaraja T. K ${ }^{1}$, Chandrashekar Shetty ${ }^{2}$ \\ ${ }^{I}$ Assistant Professor, Department of Mechanical Engineering, J S S Academy of Technical Education, Karnataka, India \\ ${ }^{2}$ Head of CS \& QA, Department of CS \& QA, Triveni Engineering \& Industries Ltd., Karnataka, India
}

\begin{abstract}
Condensing steam turbine is used in sugarcane, distillery and chemical industries for power generation. The condensing steam turbine components like casing are subjected to very high pressure and temperature during operation, so these components need to be machined very accurately. In Triveni Engineering \& Industries Ltd. it is observed that the machining of steam turbine casing under manufacturing cycle time is exceeding the estimated cycle time this resulting in casings are not available for assembly on planned date. Here an effort is made to solve the above problem by reducing the manufacturing lead time using time study and standard operations methodology.

The machining of steam turbine casing is carried out by split half condition called as top half \& bottom half steam casing. We identified the operations like white lacquering, marking, rough top \& bottom, finish top \& bottom machining requires more setup time. Milling diaphragm groove, laby bore operations are carried out on conventional Horizontal boring machine and Vertical turret CNC lathe machine which requires more setup time, loading and unloading time. In this study we identified the deviations due to which the manufacturing cycle time is more than the estimated time and we established the standard operation procedure for each operation. With this we reduce the manufacturing lead time of steam turbine casing from 42 days to 30 days. This methodology reduces the non productive time of the steam turbine casing and finally we save the manufacturing cost of steam turbine.
\end{abstract}

Keywords: Reducing, manufacturing, lead time, steam turbine casing, standard operation, cycle time. ***

\section{INTRODUCTION}

Triveni engineering business group is the largest and only dedicated turbine manufacturing unit in India. It has strong association with premier institutes such as Indian Institute of science, IIT Madras, National Aeronautical Laboratory, Gas Turbine Research \& Engineering Bangalore. It has extensive design experience with state of art design tools which helps in developing the latest designs of critical components such as rotors, blades and nozzles [1].

This paper will show how the waste reduction can be made throughout the process by using time study and standard operations methodology. It analyze the processes involved in manufacturing and identifies the key areas of wastage and possible solution to overcome them. Time study was chosen as a tool to gather information on the turbine casing manufacturing because it has been used successfully by much organization to plan and identify internal improvement. Furthermore when used appropriately it can help the process industry eliminate waste, maintain better inventory control, improve product quality, and better overall financial and operational control.

The ultimate goal of this research is to identify all types of waste in the value Stream and to take step to try and eliminate these. Waste can be part of a process that takes time and resources but adds no value to the product.

This research is based on a case study of a turbine casing manufacturing company, India. This is a part of a larger research in which the object is to identify, develop and stimulate the development and more efficient production process for use throughout the manufacturing company.

The aim of this research was to:

- Understand the 'current state' of the manufacturing company.

- Identify the key area of waste, problem and opportunities across the company.

- Develop of 'future state vision' of each of the supply chain [4].

- Increase the productivity.

- Develop an action plan to achieve the higher production and lead time reduction

\section{DATA COLLECTION AND ANALYSIS}

This section will describe the processes which take place throughout the factory and will identify problems and issue. The processes which take place throughout the factory have been summarized as follows 
- Take a turbine casing. This turbine casing is made up of different composition of metal like $\mathrm{Cr}, \mathrm{Mg}$, $\mathrm{Mo}$, steel etc.

- Then turbine casing is supplied to white lacquering for marking purpose in three set up.

- The turbine casing rough joint face is machined in Horizontal boring machine.

- Reference rough cut operation is done in Horizontal boring machine.

- Rough machining operation is performed in Vertical turret lathe which requires accurate setup and keen observation [2].

- Magnetic particle are applied on the surface of the casing and it is applied to magnetic field as a result if there are any defects it will be reworked by welding.

- The turbine casing is subjected to stress relieving and sand blasting process.

- The turbine casing is finished in horizontal boring machine.

- Reference finish cut is done in Horizontal boring machine.

- Finish machining operation is done on Vertical turret lathe.

- Finally turbine casing is inspected and assembled.

Table -1 Total number of days required to complete machining operation in present method.

\begin{tabular}{|l|l|l|l|l|}
\hline $\begin{array}{l}\text { SI. } \\
\text { No. }\end{array}$ & $\begin{array}{l}\text { List of } \\
\text { Activities }\end{array}$ & Operation & $\begin{array}{l}\text { Standard } \\
\text { time }\end{array}$ & $\begin{array}{l}\text { Actual } \\
\text { time }\end{array}$ \\
\hline 1 & Marking joint & Manual & 2 & 4 \\
\hline 2 & $\begin{array}{l}\text { Rough f-Boring } \\
\text { face }\end{array}$ & 2 & 3 \\
\hline 3 & $\begin{array}{l}\text { Mark for } \\
\text { Drilling HJF }\end{array}$ & Manual & 1 & 2 \\
\hline 4 & Reference cut & H-Boring & 1 & 2 \\
\hline 5 & $\begin{array}{l}\text { Rough } \\
\text { machining } \\
\text { VTL }\end{array}$ & VTL-CNC & 5 & 9 \\
\hline 6 & $\begin{array}{l}\text { Magnetic } \\
\text { particle test }\end{array}$ & Manual & 2 & 7 \\
\hline 7 & Finish HJF & H-Boring & 2 & 3 \\
\hline 8 & $\begin{array}{l}\text { Reference cut } \\
\text { for finishing }\end{array}$ & H-Boring & 2 & 4 \\
\hline 9 & $\begin{array}{l}\text { Finish } \\
\text { machining } \\
\text { VTL }\end{array}$ & VTL-CNC & 6 & 8 \\
\hline 10 & $\begin{array}{l}\text { Total No. of } \\
\text { days }\end{array}$ & 23 & 42 \\
\hline
\end{tabular}

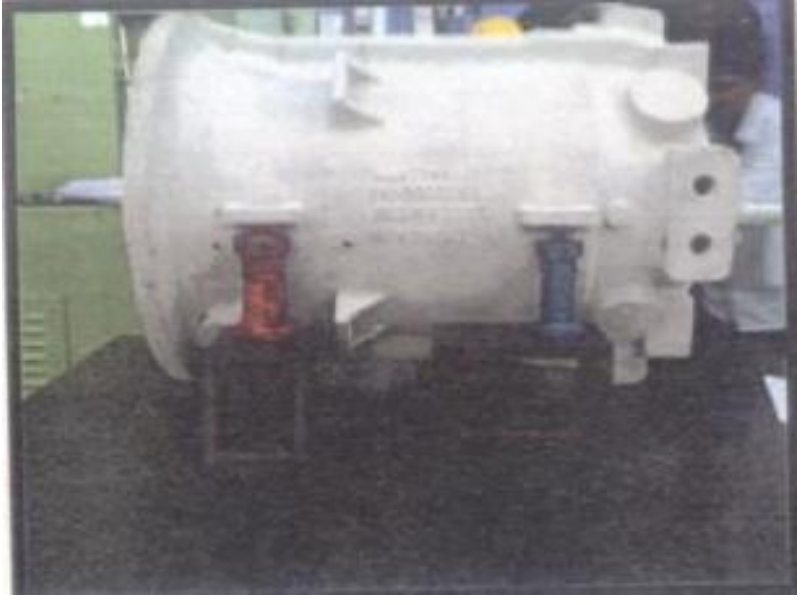

Fig-1 White lacquering

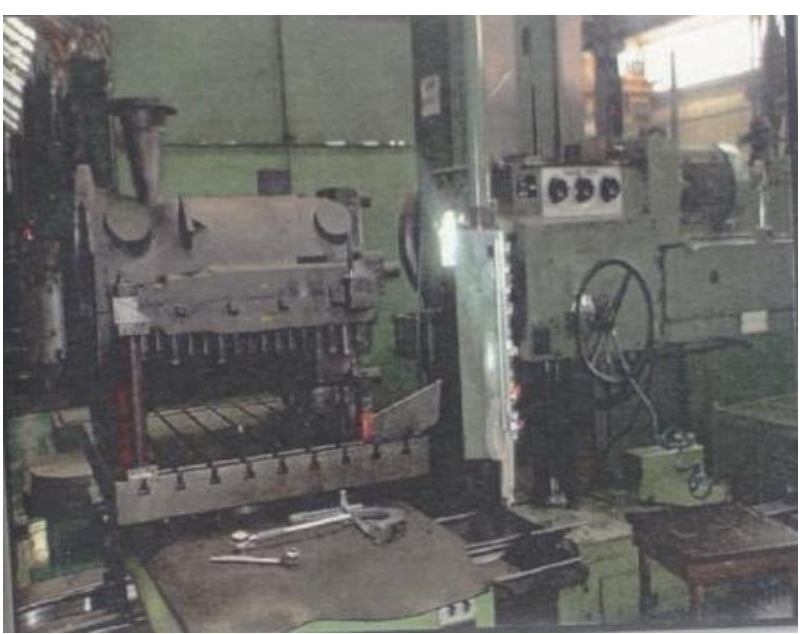

Fig-2 Horizontal boring operation

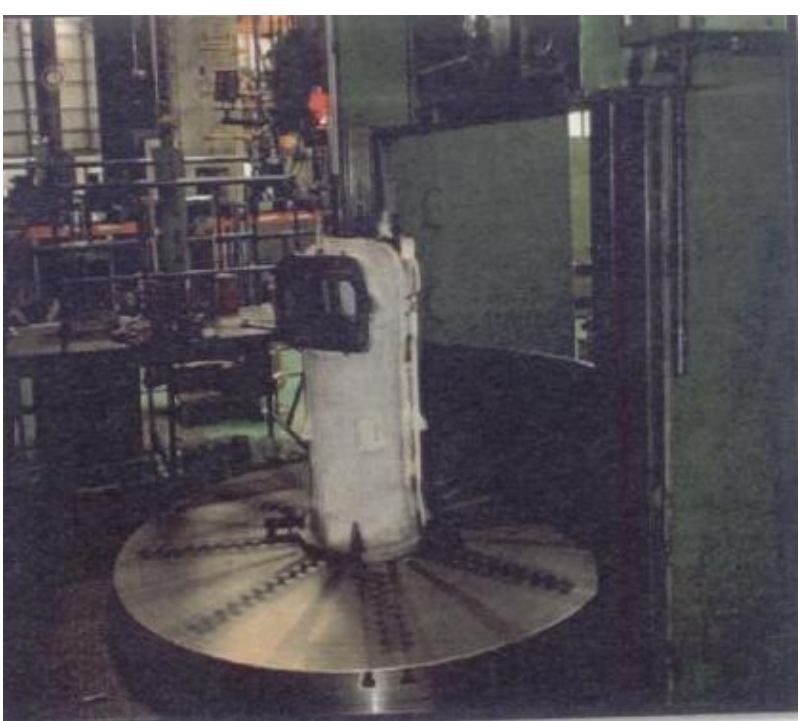

Fig-3 Rough machining in VTL 
Table -2 Processes, Cause and Corrective action

\begin{tabular}{|l|l|l|l|}
\hline $\begin{array}{l}\text { Sl. } \\
\text { No. }\end{array}$ & Process & Cause & $\begin{array}{l}\text { Corrective } \\
\text { action plan }\end{array}$ \\
\hline 1 & $\begin{array}{l}\text { White } \\
\text { lacquering }\end{array}$ & $\begin{array}{l}\text { Unavailability of } \\
\text { crane }\end{array}$ & $\begin{array}{l}\text { Make sure the } \\
\text { crane is near the } \\
\text { marking area }\end{array}$ \\
\hline 2 & $\begin{array}{l}\text { Rough joint } \\
\text { face } \\
\text { machining }\end{array}$ & Set up time & $\begin{array}{l}\text { Proper } \\
\text { arrangements of } \\
\text { setting tools }\end{array}$ \\
\hline 3 & $\begin{array}{l}\text { Marking for } \\
\text { drilling HJF }\end{array}$ & $\begin{array}{l}\text { Uneven surfaces } \\
\text { in raw casting }\end{array}$ & $\begin{array}{l}\text { Proper welding of } \\
\text { pads before } \\
\text { marking } \\
\text { operation }\end{array}$ \\
\hline 4 & $\begin{array}{l}\text { Rough } \\
\text { machining } \\
\text { VTL }\end{array}$ & $\begin{array}{l}\text { Casing is placed } \\
\text { outside work } \\
\text { table center }\end{array}$ & $\begin{array}{l}\text { Clamping of } \\
\text { casing using } \\
\text { pneumatic device }\end{array}$ \\
\hline 5 & $\begin{array}{l}\text { Magnetic } \\
\text { particle test }\end{array}$ & $\begin{array}{l}\text { Rust formation } \\
\text { on casing }\end{array}$ & $\begin{array}{l}\text { Cleaned in early } \\
\text { stage. }\end{array}$ \\
\hline
\end{tabular}

\section{METHODOLOGY /APPROACH}

We conducted the through study of three numbers of steam turbine casing and found similar problem in machining operation. Therefore we adopted the following approach for each process. Here we analyze the data collected by us basically improvement/modification is done by us in this section. Here we calculate the value addition percentage in the different process. Also we analyzed the root causes of different problems and suggested their remedial actions. Reducing the lead time by improving production

\subsection{Marking Operation}

As we discussed earlier in this process the standard time is $18 \mathrm{hrs}$ and actual time taken is $201 / 2 \mathrm{hrs}$. As, we noticed that most of the time spent in handling of material between inventory and machine. We have suggested some implementation area which will improve production as well as reduce inventory.

\subsection{Horizontal Boring Operation}

The reasons for deviation from standard time during the horizontal boring operation are uneven surfaces in raw casting and setup time. We suggested some implementation such as proper welding of pads before marking and proper usage of crane with respect to machine we can reduce loading and unloading time.

\subsection{Vertical Turret Lathe Operation}

The reasons for deviation from standard time during the vertical turret lathe operation are clamping of casing and setup time. We suggested some implementation such as clamping of casing using pneumatic device and proper usage of crane during loading and unloading to reduce setup time.

\subsection{Magnetic Particle Test}

In this process we observe there is formation of rust on the casing component and scaling. We suggested some implementation such as preparing machining defect and inspection chart after completion of operations and incase of component having rust, scaling etc. it is checked and cleaned in early stage.

\section{RESULTS AND DISCUSSION}

Table - $\mathbf{3}$ Total numbers of days required to complete machining operation after implementation new methodology.

\begin{tabular}{|l|l|l|l|l|}
\hline $\begin{array}{l}\text { Sl. } \\
\text { No. }\end{array}$ & $\begin{array}{l}\text { List oftivities } \\
\text { Action }\end{array}$ & $\begin{array}{l}\text { Operationdard } \\
\text { time ine } \\
\text { days }\end{array}$ & $\begin{array}{l}\text { Actual } \\
\text { time in } \\
\text { days }\end{array}$ \\
\hline 1 & Marking & Manual & 2 & 2 \\
\hline 2 & $\begin{array}{l}\text { Rough joint } \\
\text { face }\end{array}$ & H-Boring & 2 & 2.5 \\
\hline 3 & $\begin{array}{l}\text { Mark for } \\
\text { Drilling HJF }\end{array}$ & Manual & 1 & 1 \\
\hline 4 & $\begin{array}{l}\text { Reference } \\
\text { cut }\end{array}$ & H-Boring & 1 & 1 \\
\hline 5 & $\begin{array}{l}\text { Rough } \\
\text { machining } \\
\text { VTL }\end{array}$ & VTL-CNC & 5 & 7 \\
\hline 6 & $\begin{array}{l}\text { Magnetic } \\
\text { particle test }\end{array}$ & Manual & 2 & 5 \\
\hline 7 & Finish HJF & H-Boring & 2 & 2 \\
\hline 8 & $\begin{array}{l}\text { Reference } \\
\text { cut } \\
\text { finishing }\end{array}$ & H-Boring & 2 & 3 \\
\hline 9 & $\begin{array}{l}\text { Finish } \\
\text { machining } \\
\text { VTL }\end{array}$ & VTL-CNC & 6 & 6.5 \\
\hline 10 & $\begin{array}{l}\text { Total No. of } \\
\text { days }\end{array}$ & & 23 & 30 \\
\hline
\end{tabular}

\section{IMPROVEMENTS IN REDUCTION IN LEAD}

\section{TIME}

Lead time before improvement $=42$ days

Lead time after improvement $=30$ days

Savings in lead time $=12$ days

Table $\mathbf{- 4}$ Comparison of lead time in days

\begin{tabular}{|c|c|c|}
\hline Lead time & Before & After \\
\hline & 42 & 30 \\
\hline
\end{tabular}




\section{CONCLUSIONS}

After analyzing the root cause, process charts and results this can be concluded that the main reason for non-value added activities are long distance, wrong handling, and not proper sequence. Thus it can be concluded that in the plant the wastes is mostly in the form of these activity. With our work we reduce manufacturing lead time of casing from 42 days to 30 days. We save the manufacturing time by 12 days it saves the non productive time of the steam turbine casing thus we save the manufacturing cost of turbine.

\section{REFERENCES}

[1]. Dickers, M., HaddenS. G. C., Pfitzinger, E.W., Simon, V. Design System for Advanced Steam Turbines 2000.

[2]. Turner 1 and 2 year trade theory National Instructional media institute Chennai.

[3]. Schwarz, M.A., Heine W.H., Wechsung M.,Tame R., Niue damp turbine generation 2003.

[4]. Wu, S. Wee, H.M.: How Lean supply chain effects product cost and quality, A case study of the ford motor company 2009. 